\title{
PIK3CA Gene Mutation
}

National Cancer Institute

\section{Source}

National Cancer Institute. PIK3CA Gene Mutation. NCI Thesaurus. Code C96271.

A molecular genetic abnormality indicating the presence of a mutation in the PI3KCA

(phosphatidyl inositol 3-kinase) gene on chromosome 3q26.32. 